\title{
THE MATRILINEAL ARCHITECTURAL VALUES ON THE CONSTRUCTION OF THE MINANGKABAU HOUSE
}

\author{
HARDONO, Setiawan ${ }^{1 *}$; BAHAUDDIN, Azizi ${ }^{1}$; ABDULLAH, Aldrin ${ }^{1}$; MALIKI, Nor Zarifah ${ }^{1}$ \\ ${ }^{1}$ School of Housing, Building and Planning, Universiti Sains Malaysia, 11800 USM Pulau Pinang, MALAYSIA \\ Emails: azizi@usm.my; aldrin@usm.my; zarifah@usm.my \\ * Corresponding author: setiawan8431@gmail.com
}

\begin{abstract}
This article studies the relationship between the custom of inheritance system based on the mother's side bloodline or better known as the matrilineal system and the construction of the Western Sumatera Minangkabau house. The architectural components and the construction of the house is often related to the matrilineal custom concept which lies $\mathrm{n}$ the philosophy of beliefs, perspective and strong ritual. The objectives of this research are to identify and analyze matrilineal values and its relationships with the process of the construction and architectural features of the Minangkabau house. The process of the constructing the Minangkabau house involves completing, gathering building materials to the part of building the house. This research used repeated research methodology, past researches analysis and ethnographic methods. Data collection is done through observational processes, interviews and photo taking at various research locations. These research methodologies had verify the compatibility of matrilineal elements to the architectural features of the construction of the Minangkabau house.
\end{abstract}

Keywords: Construction process of house; Minangkabau house; architectural features; matrilineal.

\section{INTRODUCTION}

Traditional houses are ancient constructions that had been inherited for generations. The shape and and style of the traditional house contains its own unique values inside a community culture (Hanafi, 1985). The construction of the traditional house's architectural components has been heavily influenced by cultural elements. These elements have a strong base concept of custom, belief, religion and ritual beliefs. This sort of construction is different with vernacular houses because their constructions are through the values mentioned inside the traditional house (Mat, 2010). The different aspect of construction between traditional and vernacular house can be seen through the year of construction (Ariffin, 2001) and the values that have been implemented during the construction process (Is, 2000). From the cultural value aspect, it can be seen that it is related with philosophy and the point of view from man that differs according to his background, custom and custom especially those that have been influenced by the environment. In the Minangkabau house case, the basic principles used to identify a traditional Minangkabau house also include two construction aspects i.e. primitive construction and vernacular construction. Usually, a primitively constructed Minangkabau house is influenced by customary values and culture that have been inherited for generations and is significantly different from a vernacularly constructed Mingangkabau house
(Vellinga, 2004). According to Asri (2004), the Minangkabau house which is also known as the custom house is a made as a template from similar traditional houses such as other traditional houses related. This customary and cultural aspect not only appears at the physical manifestation of the house, but also during the early processes of the house's construction before it is inhabited. It has been heavily influenced from the customs practiced by the Minangkabau community, a system based on the mother's side inheritance also known as matrilineal inheritance custom. The architectural features is adorned with ritual concepts and beliefs based on the matrilineal custom and strong Minangkabau culture. The most significant basic concept is the structure of the internal arrangement that remains unchanged (Figure 1).

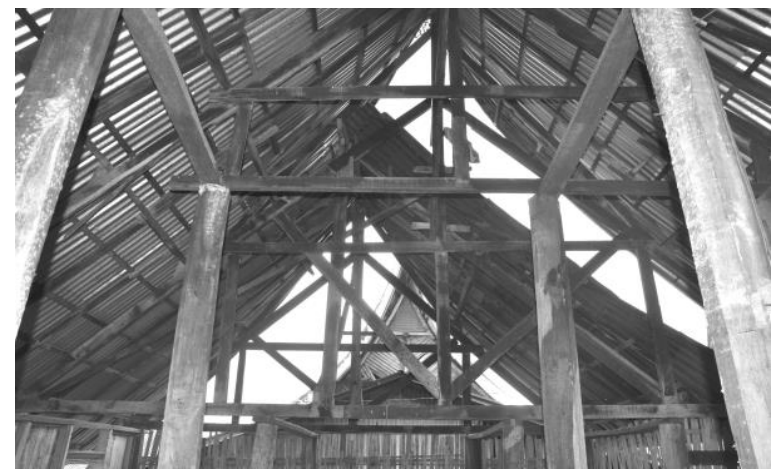

Figure 1. Internal construction house-structure 
Every feature and unit of the Minangkabau house built gives its own function and meaning, a product of influence from social relations, economic and politic inside a matrilineal system practiced by the people according to tradition. According to Asri (2004:4) again, the architectural features are shaped based on the principles of ancient construction and produced the Minangkabau house built in a uniform design. The Minangkabau house is built with permanent methods and principles, brought down since ages of generation.

\section{MINANGKABAU AND FAMILY MATRILINEAL KINDSHIP}

According to history or 'tambo', the Minangkabau culture had appeared since centuries past in Western Sumatera. It began around 3 'luhak' or provinces which consist of Tanah Datar, Agam and Kota Lima Puluh, Western Sumatera (Asri, 2004; Is, 2000; Jayatri, 2001; Widya, 2001; Soeroto, 2005). This culture then expanded to distant provinces both inside and outside of Western Sumatera. At the beginning of its existence, Minangkabau people practiced animism, a belief based on nature (Nasroen, 1957). However, after the arrival of Islam, almost all of the people held tightly to Islam until today. One of the important characteristics of the Minangkabau culture is the sense of unity among its community. They live in their own clans and often work together in deciding every decision and often cooperate. This is due to the fact that the community is united under Islamic beliefs. Although the rules of the custom are not written, the people believe that customs are mandatory rules to follow (Asri, 2004; Soeroto, 2005). The Minangkabau people had been taught with good values and had made natural elements as an example of harmonious living (Manggis, 1971). According to Hakimy (1978), the Minangkabau custom is divided into four (4) parts namely two (2) of it is known as permanent rules that cannot be amended and the other two (2) of it are flexible rules that can be amended. Permanent rules consist of the rules and regulations of Islamic beliefs. Whereas, the flexible rules that can be amended are matters relating to marriage, birth and the lot. According to the system of rules, there are (2) ruling systems among the Minangkabau community i.e. 'Koto Piliang' led by Datuk Ketemenggungan and 'Bodi Caniago' led by Datuk Perpatih. Both leaders possessed different leadership principles. Datuk Ketemenggungan ruled the Koto Piliang custom by autocratic means while Datuk Perpatih rule Bodi Caniago custom with democracy (Is, 2000; Widya, 2001).
However, both laws still implement the same matrilineal lineage system. Holistically, the identity of the Minangkabau people can be summarised in figure 2. Customs based on the mother's side inheritance that is the matrilineal lineage system is one of the unique social systems and is practiced only by certain groups of people in the world. The consistency of this system is clear and well-structured. With this, the term mothers with authority are known as matriarchate while the term for the lineage and followers of this custom is called matrilineal (Amir, 1997).

These two terms clarify that mothers and womenfolk are given privileges and special positions from the men. Firstly, the lineage is drawn according to the bloodline and family history of the mother's side. Second, individuals are required to marry to an individual from another Minangkabau clan. Third, the mother has authority over the economy and peace of the household (Amir, 1997). There are three (3) important characteristics that are emphasised in the matrilineal lineage system i.e. social, economy and leadership organisation (Figure 3). This system had shaped the way of life that is harmonious and peaceful to the people

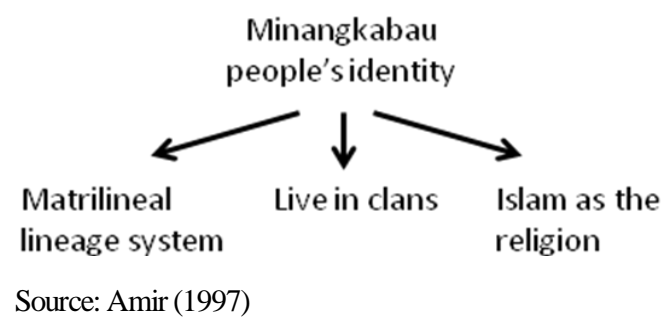

Figure 2. Identity of Minangkabau people

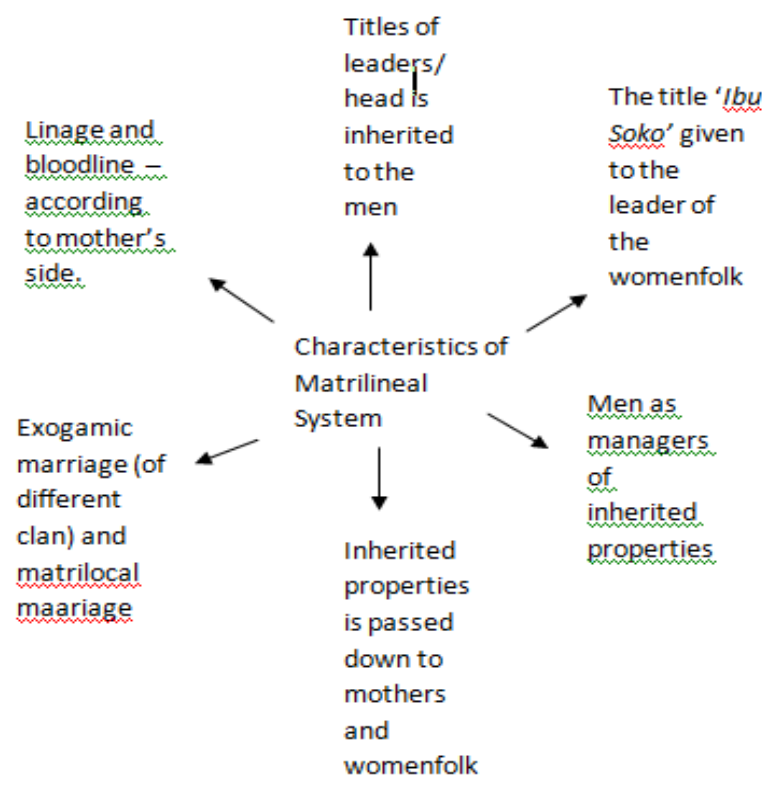

Source: Amir (1997); Jumain (1995)

Figure 3. Characteristics and identity of matrilineal system 
The women wield substantial power and role within the matrilineal system as they are regarded as the continuing factor to the heritage and the source of future generation of Minangkabau (Asri, 2004). Therefore, they are called 'Bundo Kanduang' as an acknowledgement and respect to them. They are also thought to possessed excellent leadership skills, charisma and wisdom in planning the economy (Hermayulis, 2007; Asturi \& Soedarsono, 2006). According to Asri (2004), the term family inside the matrilineal Minangkabau community means differently between other culture's definition of family. A family in a Minangkabau community consists of the mother, relatives of the mother, daughters and the mother on the mother's side. Meanwhile, a family in other cultures generally consists of the father, mother and the children. Men whom marry Minangkabau women are the husbands and fathers but they are not regarded as part of the family instead they are called newcomers or foreigners such as 'orang menumpoang' or 'orang sumando' (Selat, 1976; Ibrahim, 1993). They are not given the rights to inherit any properties from the mother (Azwar, 2001). In reality, the men inside the matrilineal system are not of priority, unless the men from the mother's side, the uncles to her daughters known as 'mamak'. They are elected as leaders known as 'tungganai' to head the house (Widya, 2001) thus act as middlemen and lead ceremonies and customary rituals held by the clan (Asri, 2004). In reality, the ancient history of the origins of matrilineal in Minangkabau culture of Western Sumatera is still unclear and a lot of it was told through various versions contained in Minangkabau history known as "Tambo" (Jumain, 1995).

\section{THE MINANGKABAU HOUSE OF WESTERN SUMATERA}

The Minangkabau house is a residential structure built and inhabited by the Minangkabau people in Western Sumatera. Besides being made as a home, this house is also regarded as the symbol of pride of the clan in every Minangkabau community living in that particular province (Soeroto, 2005; Yovita, 2012). Therefore, this house is often considered as a property owned by the clan and is always nurtured and preserved and will never be sold or never be given to other people outside of the bloodline (Soeroto, 2005). Initially, the Minangkabau house is a traditional house. However, after some evolution, this house is made as an official place to conduct customary ceremonies as well as a residential home. Therefore, the Minangkabau house is also called the 'rumah adat' or custom house. Many sort of customary events such as election of a new leader, guest-welcoming ceremonies and healing rituals of sick family members take place inside this house (Idrus, 1996; Widya, 2001). Usually, this house is resided by a big family consisting of several generations of the family such as the grandmother, mother, daughters and granddaughters (Emran, Boestami, Moechtar, Zaiful, \& Nusjirwan, 1981; Idrus, 1996). According to the laws and rules of the matrilineal custom, the mothers and daughters are given special privileges to become permanent resident and heir to the house. Sons who had reached the age of 7 (seven) will leave the house and stay at the surau owned by the clan. After they had married, they will move and reside at the houses of their wives and will be given the name 'orang sumando'. Although the custom seem like so, the men on the mother's side is still given the responsibility to manage the Minangkabau house and make sure the custom activities runs smooth. He also need to ensure that the administration of the Minangkabau house continues to be preserved. A leader known as the 'known as the 'tungganai' is elected amongst the relatives from the mother's side or 'mamak' to lead the big family that reside inside the house.

Generally, the Minangkabau house is easier to recognise from its physical aspect. The sharp-tipped design of the roof shaped like a water buffalo's horn discriminate the Minangkabau house from other traditional houses in the Nusantara region. The roof is multi-tiered with upswept gables (Figure 4). The design is very unique and every element of the architecture is related to the cutom and culture practiced by the people. The solid rules and laws that shaped the architecture of the Minangkabau house as it is. The design is suitable with natural phenomena and harmony to the residents that lives inside the Minangkabau house. There are 4 (four) natural elements that has been made base to the concept and philosophy of the design and architecture of the Minangkabau house. According to Asri (2004), this

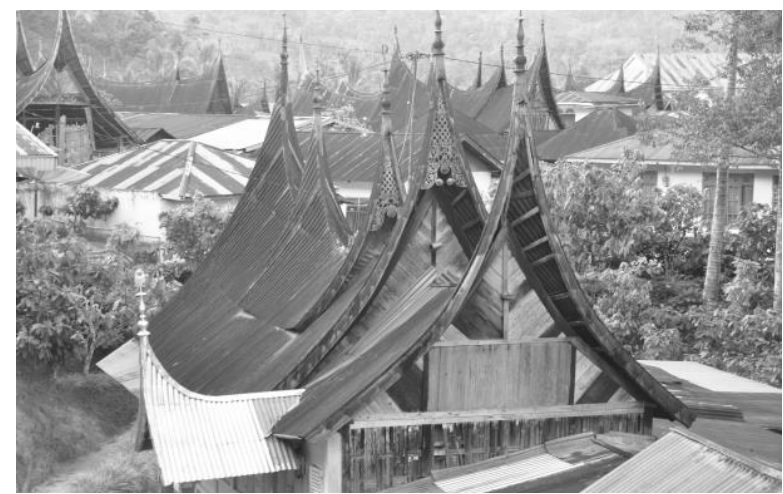

Figure 4. Minangkabau house with sharp-tipped roof 
feature can be seen at the roof design of the Minangkabau house, which has at least 4 (four) shrp tips or gabbles. The roof can be symbolise as the head of a body that gives harmony to all it's part. This feature consists of a concept called 'alam manusia berindividu' individual world of man, 'alam manusia bermasyarakat' communal world of man and 'alam yang ghaib' invisible world of man (Nasroen, 1957). Besides the roof, the pillars also has its own analogy and functions inside the Minangkabau house. The brilliance of the design of the Minangkabau house in Western Sumatera is created from the architectural features that shape the house. These features give a huge impact to the harmony of the natural environment design. The Minangkabau community made the 'alam takambang jadi guru' concept as a reference to build the Minangakabau house. This produced a brilliant architecture compatible with the environment. Until today, The Minangkabau house stands strong and maintains its dynamic architectural characteristics with the natural environment concept. Generally, every architectural feature built in the Minangkabau house has a symbol and meaning of its own. Nature had taught man that every living thing made and created in this depends on each other and gives mutual benefits to one another. This cultural philosophy of the Minangkabau people had manifested through the ornamentation and carvings of the walls, ventilation, natural lighting and building materials. All these natural components can create a brilliant structure to the architecture of the Minangkabau house. In reality, every design created to the architecture of the Minangkabau house is through the thoughts and understanding of the community in interpreting a phenomenon in order to bring serenity and harmony to the residents involving the individual, family and communal aspects.

The Minangkabau house in Western Sumatera is divided into two types according to the custom laws each one has (Figure 5). The Minangkabau house following the Koto Piliang custom laws is known as 'Rumah Beranjung' that is this house contains a balcony called anjung and levelled floors as a symbol to the autocratic rule, whereas the Minangkabau house following the Bodi Caniago is known as
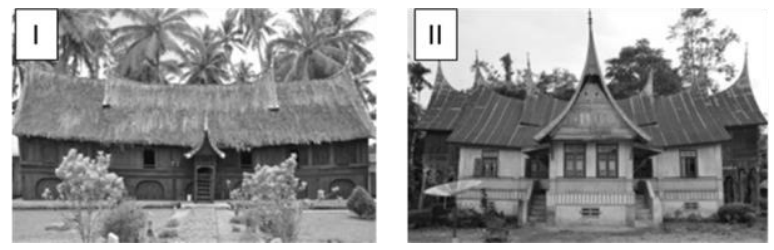

Figure 5. (I) Rumah Beranjung at Sungai Jambu, (II) Rumah Tidak Beranjung at Balimbing
'Rumah Tidak Beranjung' with no balconies and flat, same-level floors as a symbol to the democratic rule concept (Idrus, 1996; Is, 2000). Although the structure is different, both types of Minangkabau houses is built on the concept and values of belief, philosophy, ritual, custom and culture of the same community (Soeroto, 2005; Yovita, 2012). The most important thing is that the construction of the Minangkabau house needs to go to the same process.

\section{RESEARCH METHOD}

The previous related studies and the ethnographic method had been used as the reference in order to achieve the research objectives. The data collected are supported by the new information that had been gathered through the field works. Some of the Minangkabau house and traditional houses of Negeri Sembilan are being taken as the case study. Interviews with a couple of the traditional culture leaders and villagers had been carried out. Through this methodology, the researcher could understand the way of thinking and life of the villagers in details. The information on the background of the individual and the society had been collected in order to relate the relationship between the physical study as well as the social study and will succeed the research objectives. Visual data that comprises of photos and house measurement will be collected as well as be documented. The methods of collecting the data that had been mentioned above will be done simultaneously.

\section{MATRILINEAL VALUES AND FEATURES ON THE CONSTRUCTION OF THE MINANGKABAU HOUSE}

According to Sudirman Is (2000), there are three (3) stages in constructing a Minangkabau house such as shown in Figure 6. Every stage and process in constructing a Minangkabau house is influenced by philosophical beliefs, religion and ritual system concept of the matrilineal custom that is held strongly by the people.

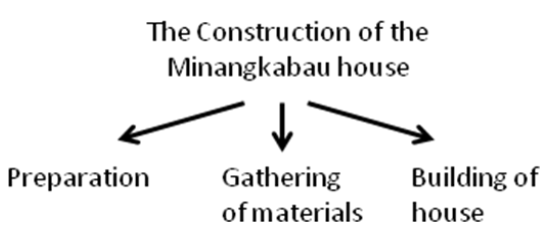

Source: Is (2000)

Figure 6. The stages of constructing the Minangkabau house. 
These values become the foundation of the architectural elements that make the Minangkabau house unique and stable until today. It is then created a harmonious and peaceful setting to the residents. The process of construction of the Minangkabau house is designed according to the matrilineal system practiced by the community. There are three aspects in the matrilineal system that is social relationship, economy and leadership hierarchy that influenced the overall planning of the Minangkabau house. Through this matrilineal lineage system, the mothers, daughters and her bloodlines are given privileges to give significance to the features of the house.

\section{Construction Preparation}

According to Figure 7, the building preparation of the Minangkabau house begins at the planning stage with the consent of everyone so that all the activities of the construction can be planned.

'Mamak tungganai' as the leader of the house needs to present proposals to build a new Minangkabau house. However, to build a new Minangkabau house, there has to be a collective agreement from all the forms all the heads of the family and community leaders. The leaders and heirs from the house up to the Nagari (state) have to agree so as to ensure that the preparation to build that house can be executed. Meetings will be held on the family level and relatives before hte proposal be brought to the highest authority. Meetings done in the family level is head by the Penghulu Andiko as the leader of the clan. People who attended the meetings include family members and relatives such as the tungganai as the head of the house, bundo kanduang as the head of the womenfolk, and others of similar ranks. After the meeting on the family level is agreed upon, the Penghulu Andiko will bring the meeting results to the state level to receive agreement form the higher authorities. Some of the important matters decided at the preparation stage of the construction of the Minangkabau house are the size, location, base of the house and suitable time to start building the house. Tukang tuo as the house mason will lead the construction of the house. He is chosen during the meeting on the state level. Tukang tuo is an important

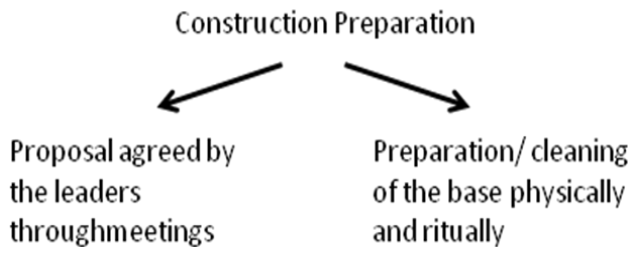

Figure 7. The stages of construction preparation figure to ensure that the house built with perfection. The preparation is done to ease the planning of the house. All activities is organised properly so that everyone in the community knows what is needed to be done. The organisation inside the matrilineal community is very strong. Usually, through this method it can increase cooperation, mutualism and helping each other regardless of individual, family or community. Every individual and community understands their duties and responsibilities.

The characteristics of the matrilineal-practicing Minangkabau community are that they very much respect their leaders. The Master of Custom and Bundo Kanduang has the authority to decide of a new Minangkabau house. Therefore, the matrilineal leaders among the men known as the head or Ketua Adat and leaders among the women or mothers known as Bundo Kanduang cooperate together when deciding the preparation of a new house. Through this approach, it can foster the matrilineal social relationship among the leaders and community as a whole. Besides that, the decision about the size of the Minangkabau house is made according to the number of daughters of the future owner of the house, agreed by the Bundo Kanduang. The size of the Minangkabau house depends on the number of rooms prepared because every daughter in a matrilineal culture is given the right to own her own room after she is married (Soeroto, 2005). Bundo Kanduang as the leader among the women has the right to agree on the shape of the of the Minangkabau house.

There are a few activities that have to be done with proper during the selection and preparation of the house's base. The base of the house has to be selected, prepared and cleaned beforehand. According to communal beliefs, base selection of the house is an important process to ensure that the house's base is truly safe and harmonious in a sense that it follows the ritualistic beliefs so that blessings is received and prevent disturbance from spirits. There are a few things done by the shaman during this ritual. Among the rituals done is placing yellow rice grains into coconut shells and are planted to every corners of the base and left for three (3) days. On the third day, the planted shells will be opened. If there is a poisonous insect such as scorpions inside the coconut shell, it indicates that there is impending doom or bad luck upon the house if it is built. Therefore, that base is not suitable to build a house and has to move to another base. The philosophy of the Minangkabau people regard this cleansing ritual approach as a factor that can increase a harmonious social relationship among the residents and economy to every individual that lives in the house is preserved because of the fortune 
they gained. Symbolically, the purpose of this ritual is to give confidence to the residents so they will feel comfortable, peaceful and harmonious living in the house. After this matter is completed, the physical cleaning process of the base can be executed.

\section{Collection of Building Materials}

The size of the house is determined earlier on during the preparation stage to facilitate the gathering of the types and number of building materials. Every physical elements of the house built will depends on the collection of the building materials. The gathering of the material is done with the help of everyone in the community. This is the foundation of the matrilineal society, when the people has strong social relationship and help one another regardless of individual, family and community. The main activity of the gathering of the building materials is to find wood in the forest together, to be made as the pillars of the Minangkabau house. According to the rituals and customs, these pillars have its own name (Figure 8).

The process of finding these pillars has to be supervised and lead by a skilful tukang tuo. According to the community's belief, every tree in the forest has a spirit or guardian, known as specific forest spirits. If the way to select a tree and the way the tree is cut down is not suitable and wrong, there may be detrimental effects and ills befallen to the strength of the house and the residents soon. Therefore, the methods of selecting a tree have to go through a ritual technique from its guardian. That is why, the physical characteristics of the Minangkabau house built includes centuries of sturdiness and stableness. This concept of selecting and gathering of these materials reflects the values of customs and rules that is compulsory to be followed by all followers of the matrilineal custom. This is because the natural elements are part of life that has been a foundation to the culture of the Minangkabau people.

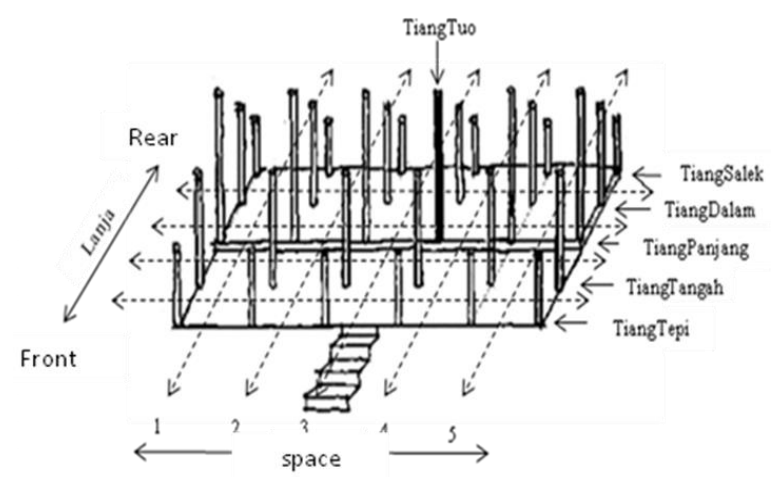

Figure 8. Names of pillars and their position
The trunk of the tree that will be made into a pillar will be select with care. According to tradition, from all the numbers of trees picked, there is one (1) type of tree that will be made into the main pillar of the house, known as tiang tuo (lit. Old pillar). The selection of the tree that will be made into a tiang tuo has to be perfect because it is considered to be head of all the pillars. During the construction of the house, the tiang tuo will be erected first before other pillars. The tiang tuo is regarded as a sacred pillar that will give strong relation to the matrilineal custom and considered a symbol of the bundo kanduang leadership. According to Is (2000), the picked tree meant to be the tiang tuo has to be a tree picked from the highest ground and on fertile land. Suitable with its function as a prestigious pillar with high status and pedigree, believed to symbolise the strength and stability of all the elements of the built house's architecture. After all the trees are collected, the next stage can precede which is the soaking and preservation process. According to Idrus (1996), this soaking and preservation of the wood is known as meramu process. Through this process, the wood meant to be made as the main pillar structure of the house will be stronger and sturdier. A wood will be soaked in water for a few certain times until is confirmed of the strength. According to the people's belief, the woods soaked will possess a sturdiness and malleability and will not be attacked by insects such as termites. Therefore, although the wood is centuries old, it is possess its authenticity and sturdiness.

The next process is piercing the pillar, making it the installing concept of "lubang dan putting". The bundo kanduang will be one of the few important figures to conduct the ceremony ritual during the piercing of this hole. According to a tukang tuo in Sungai Beringin, luhak 50 Koto named Encik M.Yunir, jewelleries such as gold and silver necklaces will be buried inside the pierced hole made. Symbolically, the purpose of such action is to indicate the heiress and ownership of the house as a inherited heritage. The measurements used during the making of the structure of the physical features of the house such as floor position, walls and windows, doors and the rest refers to body measurements of the bundo kanduang such as feet measurement, arm, body and the rest parts of the body. This custom is used to show respect of the bundo kanduang as the owner of the properties and heiress to the Minangkabau house. Physically, the purpose of this action is to give comfort to the residents namely the bundo kanduang as to suits her body. 


\section{Constructing the Minangkabau House}

Before the Minangkabau house is built, the installation of the pillars shaped into the basic structure of the house has to be executed on the ground through lying in on the ground. Next, there are three (3) stages in this process of constructing the Minangkabau house. Firstly, it started with the erection of the pillar. Symbolic to this custom and ritual, during the erection of the pillar, the tiang tuo will be covered with a piece of clothing worn by the bundo kanduang and wrapped and tied with a special rope. During this ritual, the special rope tied to the tiang tuo will be held by the bundo kanduang and pulled together with the villagers. Logically, this purpose to acknowledge and introduce the bundo kanduang as the heir and owner of said house to the public. After all the pillars are in place, the second stage of constructing the Minangkabau house will precede which is to install the roof of the house. Either the house has an attic or not, this decision will be made during this stage. The installation of the roof is proper and unique. All Minangkabau house is installed with upswept gables and multi-tiered with sharp tips. According to villagers' explanation, this symbol explains the subtle languages of the custom used by the matrilineal society that means a society that is flexible, soft and filled with elaborate language. The installation of the $i j u k$ roof during the ritual ceremony is done with the tukang tuo's mantra reading.

Next, the process of constructing the Minangkabau house is done with installation of the floor, wall and wall opening such as windows and doors and lastly is the pillar below the house. The floor is installed with certain levels as a symbol to show the status and position of the leaders like bundo kanduang, heads such as custom leaders. The walls at the side and the back of the house are installed with bamboo known as weaved sasak.

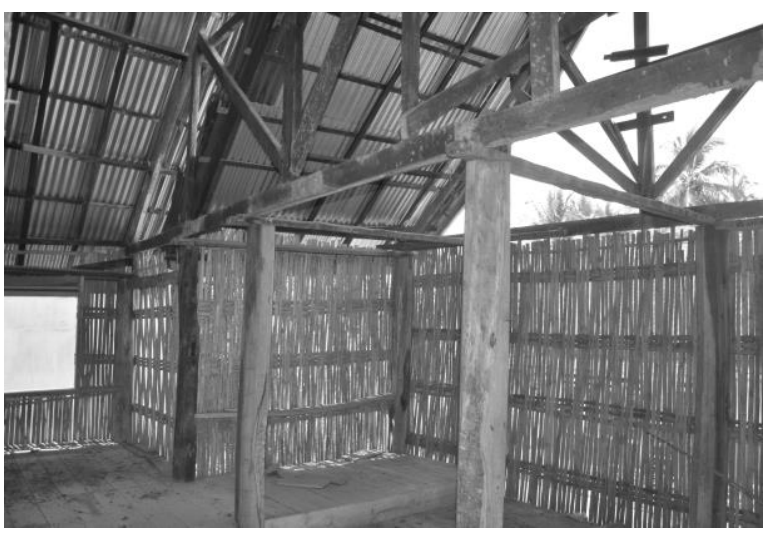

Figure 9. Wall structure weaved from bamboo
According to the beliefs of the custom and rituals, the purpose of the walls being installed with bamboo is to protect the residents of the house especially the matrilineal daughters who live in the room spaces from evil doings such as black magic. The opening of the walls such as windows at the front is to give air ventilation and natural lighting. Logically, sunlight entering the house in the morning is good for the health of the residents. Many of the orientation of the front part of the Minangkabau house is facing where the sun rises. Whereas the walls at the back of the house is not installed with windows to prevent trespassing into the rooms resided by the matrilineal daughters. After all these physical elements of the house's construction is built, the final process to erect the joint pillar below the house. The installation of the joint pillar (base) gives a huge meaning to the Minangkabau custom and culture. It tells of the social relationship in executing Islamic laws and customs. It is an analogy of the strength of the relationship between the custom and religion that complements each other. The installation of the joint pillar as the base pillar will further strengthen the house.

\section{CONCLUSION}

Based on the explanations given, it can be concluded that every feature of the physical structure of the Minangkabau house built during the construction process has its own meaning and significance relating to the concept and values of the matrilineal lineage system. The planning of the construction of design of the Minangkabau house exists as a result from the point of view and matrilineal lineage philosophy practiced since centuries past. This is parallel to the way of life of the Minangkabau people that regard nature as a concept and reference to life. Every architectural feature created produced a harmonious and peaceful structural shape and space to the residents. The residents of the home is confident that this construction concept has gone through a long process in order the community a new life in a form of a new Minangkabau house. Therefore, the physical features of the Minangkabau shaped are dominated by all the matrilineal characteristics mentioned earlier such as economic stability, social relationship, and the leadership of the matrilineal community. Therefore, the Minangkabau house that is built since hundreds of years past still stand strong and can shelter the Minangkabau people that held strongly to their customs. The physical strength reflects the matrilineal values inside the Minangkabau culture that remains strong and continuous until today. 


\section{ACKNOWLEDGEMENTS}

The authors would like to acknowledge the Universiti Sains Malaysia for funding this research under the Research University Individual Grant (RUI) 1001/PPBGN/816196 and the School of Housing, Building and Planning, Universiti Sains Malaysia for this research project.

\section{REFERENCES}

Amir, M.S. (1997). Adat Minangkabau : Pola Dan Tujuan Hidup Orang Minang. Jakarta: Citra Harta Prima.

Ariffin, S.I. (2001). Order in Traditional Malay House Form. Tesis Ph.D: Oxford Brooks University.

Asri, S. (2004). Prinsip-Prinsip Pembinaan Rumah Adat Minangkabau. Johor: Tesis Ph.D, Universiti Teknologi Malaysia.

Asturi, F., \& Soedarsono, R. (2006). Perempuan Dalam Seni Pertunjukan Minangkabau: Suatu Tinjauan Gender. Akademika Jurnal Kebudayaan, 4(1).

Azwar, W. (2001). Matrilokal dan Status Perempuan dalam Tradisi Bajapuik Yogyakarta: Galang Press.

Erman, M., Boestami, Moechtar, M. S., Zaiful, A. \& Nusjirwan, A. (1981). Rumah Gadang Minangkabau. Padang: Proyek Pengembangan Permuseuman Sumatera Barat.

Hakimy, I. (1978). Rangkaian Mustika Adat Basandi Sarak di Minangkabau. Bandung: Remaja Karya.

Hanafi, Z. (1985). Kompedium Sejarah Seni Bina Timur. Penang: Universiti Sains Malaysia.

Hermayulis. (2007). Peranan dan Kedudukan Perempuan dalam Adat Perpatih. Adat Perpatih: Esei Pilihan, pp. 105-126.

Ibrahim, N. (1993). Adat Negeri Sembilan Melalui Masa. Warisan, 17, p. 7-51.
Idrus, Y. (1996). Rumah Tradisional Negeri Sembilan. Shah Alam: Fajar Bakti.

Is, I. (2000). Kajian Nilai-Nilai Budaya Pada Ekspresi Tata Ruang Dalam Rumah Adat Minangkabau: Kes Kajian: Luhak Tanah Datar Sumatera Barat. Johor: Tesis Ph.D., Universiti Teknologi Malaysia.

Jayatri, A. (2001). Rencana Induk Lanskap Kawasan Wisata Budaya Kompleks Istana Pagaruyung, Sumatera Barat. Bandung: Tesis Sarjana, Institut Pertanian Bogor.

Jumain, A. (1995). Asal Usul Adat Perpatih Dan Adat Temenggung: Suatu Analisis Tambo-Tambo Minangkabau Berasaskan Strukturalisme. Bangi: Universiti Kebangsaan Malaysia.

Manggis, R. (1971). Minangkabau : Sejarah Ringkas dan Adatnya. Padang: Sridharma.

Mat, N. (2010). Ciri-Ciri Fizikal Ruang Dalaman Rumah Melayu : Kajian Kes Rumah Bumbung Melayu Perak. Penang: Tesis Ph.D, Universiti Sains Malaysia.

Nasroen, M. (1957). Dasar Falsafah Adat Minangkabau. Jakarta: Bulan Bintang.

Selat, N. (1976). Sistem Sosial Adat Perpatih. Kuala Lumpur: Utusan Melayu (M) Berhad.

Soeroto, M. (2005). Pustaka Budaya dan Arsitektur Minangkabau. Jakarta: Myrtle Publishing.

Vellinga, M. (2004). A family Affair: The Construction of Vernacular Minangkabau Houses. Indonesia and the Malay World, 32(92).

Widya, D. (2001). Kajian Arsitektur Rumah Tinggal Tradisional Minangkabau Nagari Panyalaian Kabupaten Tanah Datar. Semarang: Tesis Magister: Universitas Diponegoro.

Yovita, W. (2012). Budaya Matrilineal Masyarakat Minangkabau Pada Arsitektur Rumah Gadang. Retrieved Februari 14, 2012, from http://www. scribd.com/doc/46656529/Budaya Matrilineal Masyarakat Minangkabau pada Arsitektur Minangkabau. 